\title{
LATE MIDDLE CAMBRIAN TRILOBITES FROM TRIAL RIDGE, SOUTHWESTERN TASMANIA
}

\author{
by J.B. Jago \& A.V. Brown
}

(with one table, one text-figure and three plates)

Jago, J.B. \& Brown, A.V., 2001 (31:xii): Late Middle Cambrian trilobites from Trial Ridge, southwestern Tasmania. Pap. Proc. R. Soc. Tasm. 135: 1-14. https://doi.org/10.26749/rstpp.135.1 ISSN 0080-4703. School of Geoscience, Minerals and Civil Engineering, University of South Australia, Australia 5095 (JBJ); Mineral Resources Tasmania, PO Box 56, Rosny Park, Tasmania, Australia 7018 (AVB).

The first Middle Cambrian trilobites to be described from southwestern Tasmania come from two localities within siltstone in the Trial Ridge area on the HUNTLEY 1:50 000 sheet. Sixteen trilobite taxa are described. The 11 agnostoid species include one new species, Hypagnostus trali. Lisogoragnostus is recorded for the first time in Tasmania. The faunas of both localities are of a very similar late Middle Cambrian age, probably high in the Lejopyge laevigata Zone on the northern Australian biostratigraphic scale. One fauna is dominated by complete specimens of Goniagnostus nathorsti but has very few polymeroids. In the other fauna, there are no complete agnostoids, $G$. nathorsti is absent, and the most common trilobite is a member of the Proasaphiscidae, thus suggesting that the former fauna is of deeper water origin than the latter

Key Words: Middle Cambrian, trilobites, Trial Ridge, southwestern Tasmania.

\section{INTRODUCTION}

During the mapping of the HUNTLEY 1:50 000 Geological Atlas Map Sheet (Brown et al. 1982) new fossil faunas were found in two localities on Trial Ridge. The southern locality (no.1, fig.1), yielded a fauna with abundant agnostoid trilobites, numerous phosphatic brachiopods as well as polymeroids and trilobite tracks. The northern locality (no.2, fig. 1) contains a similar but more restricted fauna. The trilobites described in this paper allow their horizon to be dated as late Middle Cambrian, the first of that age to be described from southwestern Tasmania.

\section{Geological Setting}

The term "Trial Ridge Beds" was introduced by Corbett (1970) for the succession of sedimentary rocks on Trial Ridge. In the course of mapping the Huntley Quadrangle the sequence on Trial Ridge was re-mapped in greater detail than previously, allowing the rocks within the area to be subdivided into three members. The lowest member $(\mathrm{Cml}$, fig. 1) comprises thickly bedded, siliceous, granule to cobble conglomerate and siliceous sandstone. The fossiliferous middle member (Cmm, fig. 1 ) consists of thinly and monotonously interbedded light to dark-grey sandstone and siltstone. Some siltstone units contain abundant muscovite whereas, in other places, siltstone beds contain a sand-grade component. Most of the siltstone beds contain multiple truncated cross-bedding, with some of the interbedded sandstone units having silt-grade basal flame structures. The highest member (Cmh, fig. 1$)$ consists of an irregularly interbedded sequence of granule to cobble conglomerate, siliceous pebbly sandstone and siltstone. A detailed description of this succession is contained in Brown et al. (1989: 40-45).

\section{Composition and Age of the Faunas}

Locality 1 contains the following agnostoid trilobites: Goniagnostus nathorsti (Brøgger), Lejopyge laevigata (Dalman), Hypagnostus trali sp. nov., Lisogoragnostus sp., Oidalagnostus changi Lu, Clavagnostus cf. repandus (Westergård), Glaberagnostus sp., Valenagnostus sp. and Agnostoid gen. et sp. indet. Polymeroid trilobites present are Amphoton sp. and Papyriaspididae gen. et sp. indet. Trace fossils, probably formed by polymeroid trilobites, are also present.

The following agnostoid trilobites are present at Locality 2: Lejopyge laevigata (Dalman), Hypagnostus trali sp. nov., $H$. brevifrons (Angelin), Ammagnostus laiwuensis (Lorenz), Oidalagnostus changi Lu and Agnostoid gen. et sp. indet. Polymeroid trilobites present are Fuchouia sp., Bathyuriscus(?) sp. and Proasaphiscidae gen. et sp. indet.

The overlap in the faunal compositions suggests that the two faunas are of similar, if not identical, age. The combination of Lejopyge laevigata, Goniagnostus nathorsti, Hypagnostus brevifrons, Ammagnostus laiwuensis, Clavagnostus cf. repandus and Oidalagnostus changi suggests correlation with the $L$. laevigata Zone on the northern Australian biostratigraphic scale. Amphoton and Fuchouia are well-known late Middle Cambrian genera from China and Australia. The specimens described herein as Proasaphiscidae gen. et sp. indet. belong in a genus known from several localities elsewhere in Tasmania. These include Native Track Tier and St Valentines Peak (see Laurie $e t$ al., 1995, for details of these localities), where the faunas are both of very late Middle Cambrian age (Bao 1995). The combination of the above species suggests an age high in the L. laevigata Zone on the northern Australian biostratigraphic scale or near the boundary of the L. laevigata and Proagnostus bulbus Zones of the late Middle Cambrian of China (Peng \& Robison 2000).

The composition of the agnostoid component of both localities (table 1) shows that, while there are similarities in the composition of the faunas from the two localities, there 

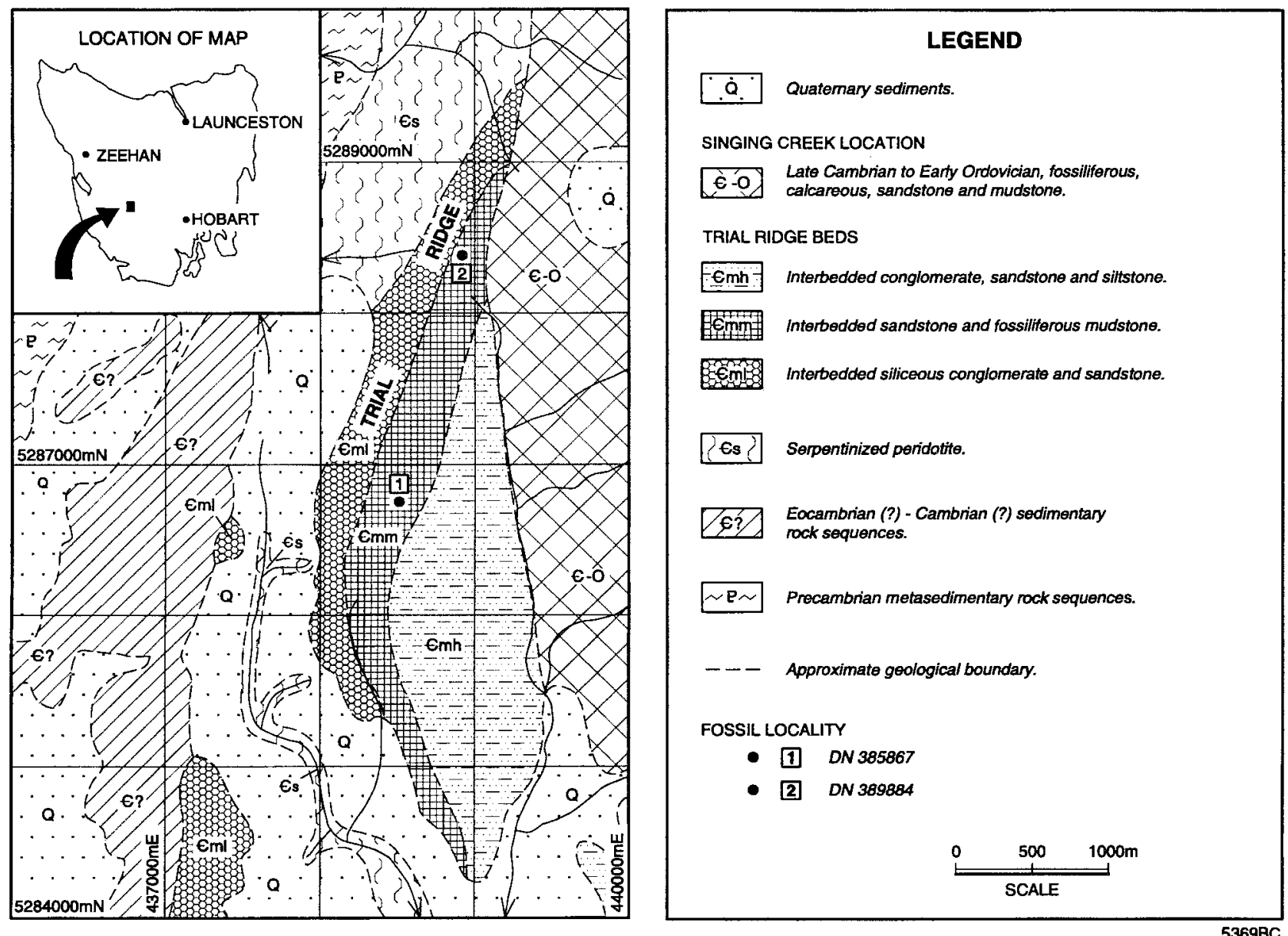

FIG. 1 - Geology of the Trial Ridge area showing fossil localities: (1) southern, (2) northern.

are also some differences. At Locality 1, 59.77\% of the known agnostoid cephala and pygidia are found in complete specimens (table 1); Goniagnostus nathorsti makes up $67.82 \%$ of the agnostoid fauna and only three polymeroid specimens are known.

In contrast to Locality 1 , there are no known complete agnostoids from Locality 2, G. nathorsti is not present, and polymeroid trilobites make up about $50 \%$ of the trilobite fauna. Of the polymeroids, Proasaphiscidae gen. et sp. indet. is the most common trilobite at Locality 2. As noted above, this species is also common in faunas of similar age at Native Track Tier and St Valentines Peak in northern Tasmania. The abundance of complete agnostoids, particularly $G$. nathorsti, at Locality 1 and the absence of $G$. nathorsti and the presence of abundant Proasaphiscidae gen. et sp. indet. at Locality 2 all suggest that the faunas of Localities 1 and 2 respectively fit into Faunas 2 and 3 of Jago (1973), with the Locality 1 fauna being a deeper water fauna than that of Locality 2.

\section{SYSTEMATIC PALAEONTOLOGY}

All specimens described occur as internal and external moulds in weathered siltstone. For description, silicone rubber casts of the external moulds were prepared and then photographed after whitening with magnesium oxide. The terminology used for agnostoid trilobites is essentially that of Shergold et al. (1990). Specimens are housed in the collection of the School of Earth Sciences, University of Tasmania.

\section{DESCRIPTIONS}

\section{Order AGNOSTIDA Salter, 1864 \\ Superfamily AGNOSTOIDEA M'Coy, 1849 Family PTYCHAGNOSTIDAE Kobayashi, 1939 \\ Genus Goniagnostus Howell, 1935b}

\section{Synonymy}

See Lu \& Lin 1989: 97. To this should be added Laurie 1989: 176; Shergold et al. 1990: 39; Peng \& Robison 2000: 71.

\section{Type species}

Agnostus nathorsti Brøgger 1878: 68, pl. 5, fig. 1.

\section{Remarks}

The generic and subgeneric classification of Ptychagnostus, Goniagnostus and related taxa has long been problematic (e.g. Ópik 1961, 1979, Robison 1964, 1982, 1984, Laurie 1988, 1989, Westrop et al. 1996, Peng \& Robison 2000). We follow Peng \& Robison in rejecting the subgeneric subdivisions of the genus as proposed by Öpik (1979). 
TABLE 1

Analysis of agnostoid trilobites from Trial Ridge*

\begin{tabular}{|c|c|c|c|c|c|}
\hline LOCALITY ONE & $\begin{array}{l}\text { Complete } \\
\text { specimens }\end{array}$ & $\begin{array}{l}\text { Separate } \\
\text { cephala }\end{array}$ & $\begin{array}{c}\text { Separate } \\
\text { pygidia }\end{array}$ & $\begin{array}{c}\text { Total } \\
\text { no. of } \\
\text { specimens }\end{array}$ & $\begin{array}{c}\text { Total } \\
\text { cephala and } \\
\text { pygidia }\end{array}$ \\
\hline Goniagnostus nathorsti & 21 & 10 & 7 & 38 & 59 \\
\hline Lejopyge laevigata & 2 & 2 & 2 & 6 & 8 \\
\hline Hypagnostus trali & 1 & & 1 & 2 & 3 \\
\hline Lisogoragnostus sp. & 1 & & 1 & 2 & 3 \\
\hline Oidalagnostus changi & & 6 & 1 & 7 & 7 \\
\hline Clavagnostus cf. repandus & & & 2 & 2 & 2 \\
\hline Glaberagnostus sp. & 1 & & & 1 & 2 \\
\hline Valenagnostus sp. & & & 2 & 2 & 2 \\
\hline Agnostoid gen. et sp. indet. & & 1 & & 1 & 1 \\
\hline
\end{tabular}

Total number of cephala and pygidia $=87$. Number of cephala and pygidia in complete specimens $=52$. Percentage of cephala and pygidia in complete specimens $=59.77 \%$.

\begin{tabular}{lccccc}
\hline LOCALITY TWO & $\begin{array}{c}\text { Complete } \\
\text { specimens }\end{array}$ & $\begin{array}{c}\text { Separate } \\
\text { cephala }\end{array}$ & $\begin{array}{c}\text { Separate } \\
\text { pygidia }\end{array}$ & $\begin{array}{c}\text { Total } \\
\text { no. of } \\
\text { specimens }\end{array}$ & $\begin{array}{c}\text { Total } \\
\text { cephala and } \\
\text { pygidia }\end{array}$ \\
Lejopyge laevigata & 3 & 2 & 5 & 5 \\
Hypagnostus trali & 1 & 1 & 1 & 1 \\
H. brevifrons & 3 & 1 & 4 & 1 \\
Ammagnostus laiwuensis & 3 & 3 & 6 & 4 \\
Oidalagnostus changi & 4 & & 4 & 4 \\
Agnostoid gen. et sp. indet. & & & 4 & 6 \\
\hline
\end{tabular}

* Every available agnostoid cephalon and pygidium is shown on this table. Each individual cephalon and pygidium is counted as one unit; thus a complete agnostoid comprises two units.

\section{Goniagnostus nathorsti (Brøgger, 1878) PI. 1A-K}

\section{Synonymy}

See Peng \& Robison (2000: 72)

\section{Material}

Twenty-one complete, or nearly complete, specimens, plus ten separate cephala and seven separate pygidia. Specimens UTGD 125320a, b, 125321a, b, 125322-125324, 125325a, b, 125326a, b, 125328-125330.

\section{Diagnosis}

See Laurie (1989: 177).

\section{Description}

Cephalon slightly larger than pygidium, with weakly and finely pustulose surface; cephalon slightly wider than long. Well-developed radial scrobicules. Narrow border; narrow, shallow border furrow. Very short cephalic fulcral spines. Unconstricted acrolobe. Well-developed preglabellar median furrow. Well-defined axial furrows. Glabella length $0.75-$ 0.8 that of cephalon; width about one-third of cephalon. Subtriangular anteroglabella has length about 0.4 that of glabella. F3 well developed; deflected slightly forwards centrally. F1, F2 well developed, extend about one-third of distance into glabella from either side; central part of posteroglabella raised well above lateral parts of glabella. Some specimens (e.g. pl. 1A) have shallow longitudinal furrows that separate the central and lateral parts of the glabella. Central part of glabella increases in height posteriorly. Small subtrapezoidal basal lobes.

Pygidium slightly wider than long. Low pustules on pleural areas coalesce to form a reticulate prosopon. Narrow, shallow border furrow; border widens posteriorly. Short posterolateral spines placed behind axial termination. Large shoulders and facets. Shallow postaxial median furrow shallows posteriorly to border furrow. Pygidial axis outlined by well-developed axial furrows. Axis about $0.7-0.8$ length of pygidium; well-developed rosette with node. Axis constricted at M2 and at rosette. F1, F2 well developed. Central part of M1 and particularly M2 separated from lateral parts of axis by shallow longitudinal furrows that are more clearly developed on M2. Central part of M2 extends into a node that continues on to posteroaxis.

\section{Discussion}

These specimens fit into Goniagnostus nathorsti as discussed by Laurie (1989) and Peng \& Robison (2000). G. nathorsti, as figured by Westergård (1946: pl. 12, figs 12-16), Öpik (1979: pl.47, fig.6; pl.60, figs 1-5; pl.61, figs 1,3-6), Xiang \& Zhang (1985: pl. 20, figs 1-3, 6-10), Laurie (1989: fig. 1) and Peng \& Robison (2000: fig. 56), shows considerable morphological variation. Variable features include the length of the glabella, the length and width of the pygidial axis and the position and length of the pygidial posterolateral spines. The Trial Ridge specimens show a similar variation, with some of the differences in appearance of the Tasmanian specimens, when compared to the specimens figured in the above papers, being due to the fact that the Trial Ridge 

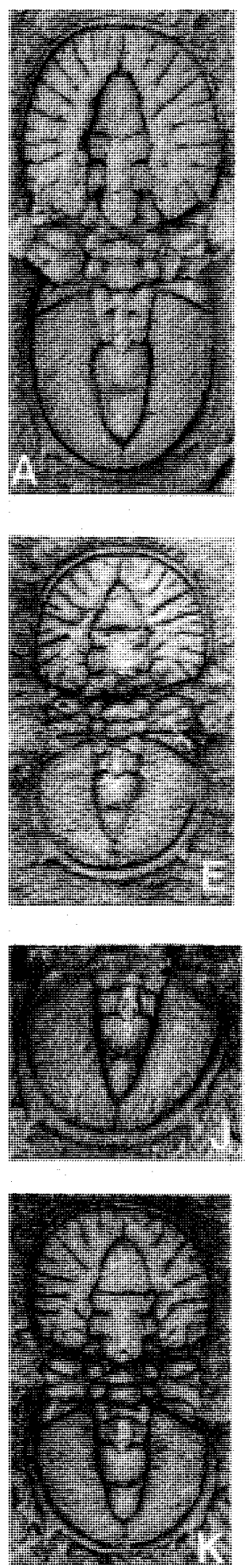
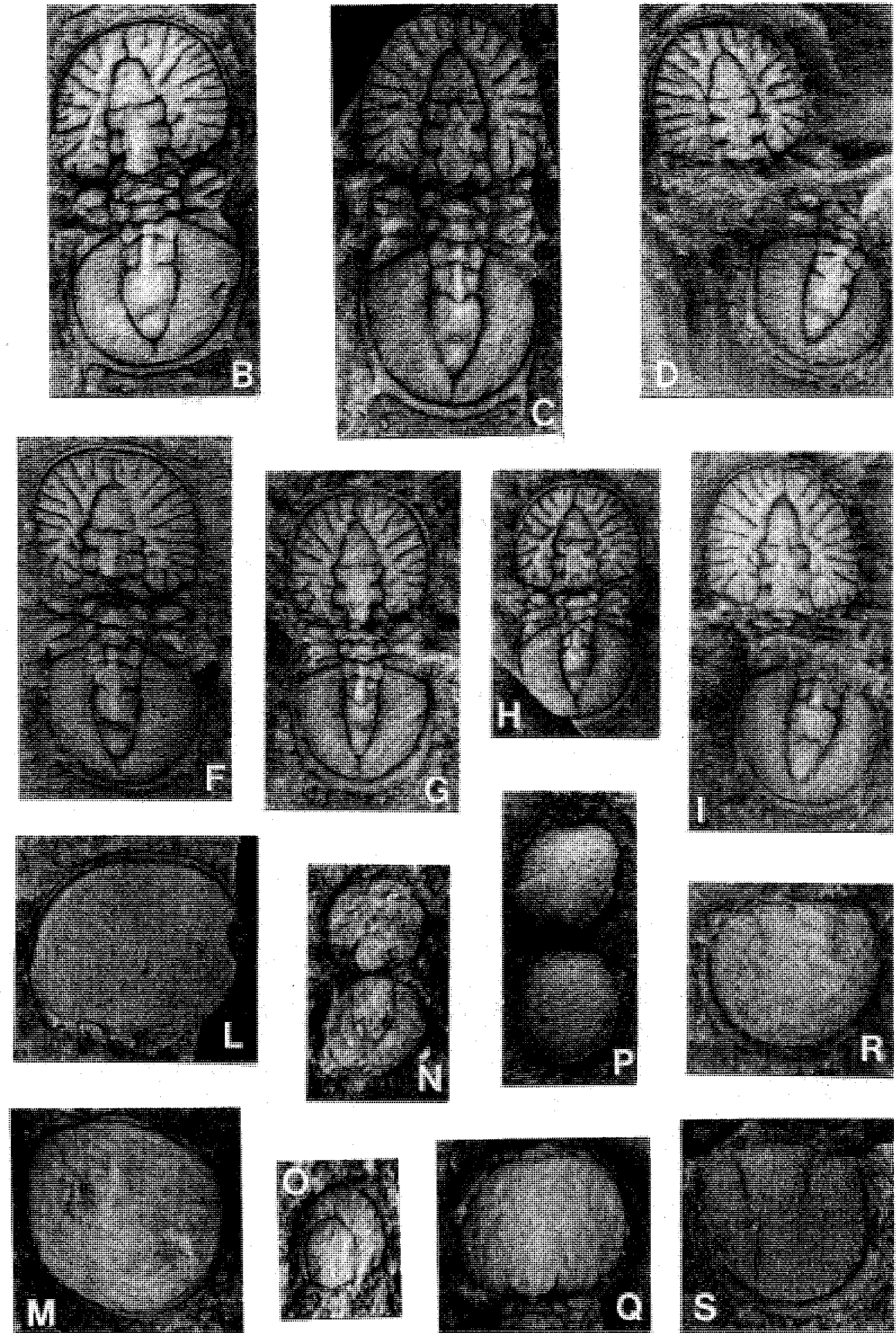
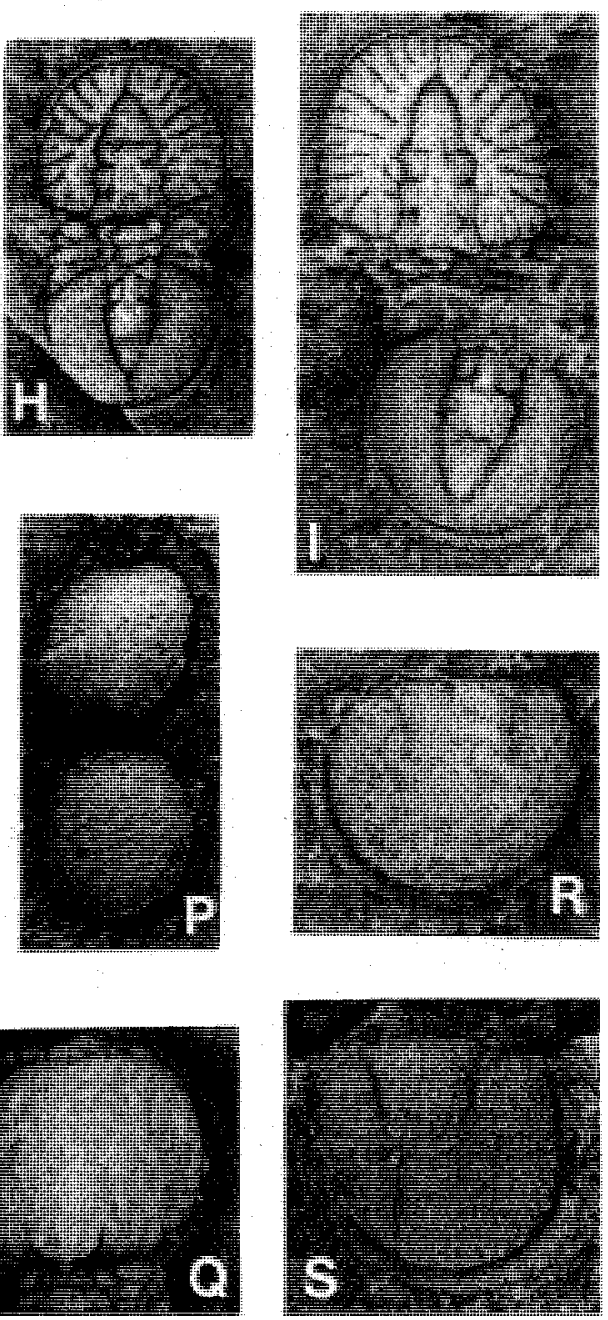
specimens are preserved in a siltstone rather than a limestone. The pygidial spines of the Trial Ridge specimens are longer than most of those shown in the specimens figured by Westergård (1946), Öpik (1979), Xiang \& Zhang (1985), Laurie (1989) and Peng \& Robison (2000). However, the pygidium figured by Laurie (1989: fig. 1B) has spines of similar length.

The pattern of scrobicules on $G$. nathorsti as figured herein is very similar to that of $G$. spiniger (Laurie 1989: figs 5, 6; Lu \& Lin 1989: pl.8, figs 9-12), even down to the small scrobicules arising from the axial furrows just behind $\mathrm{F}_{2}$. The fact that the only real difference between spiniger and nathorsti is the length of the cephalic and pygidial spines raises the question as to whether there should be a single species covering specimens normally described under $G$. nathorsti and $G$. spiniger. This is supported when it is noted that the spines in the specimens described from northwestern Tasmania by Jago (1976a) as Ptychagnostus buckleyi and placed in synonymy with spiniger by Laurie (1989) are intermediate in size between those of spiniger illustrated by Laurie and those of nathorsti illustrated herein. It could be argued that spiniger from Queensland, buckleyi from northwestern Tasmania and nathorsti from Trial Ridge are simply geographic variants of a single species. However, the difference in the spines of spiniger and nathorsti is so marked that the writers feel the continued separation into two species is warranted.

\section{Genus Lejopyge Hawle \& Corda, 1847}

Type species

Battus laevigatus Dalman 1828: 136.

\section{Remarks}

The concept of Lejopyge has been discussed at some length by Daily \& Jago (1975), Öpik (1979), Robison (1984, 1994), Laurie (1989), Westrop et al. (1996) and Peng \& Robison (2000). On the basis of cladistic analysis Robison (1994) placed Onymagnostus in synonymy with Lejopyge. However, also on the basis of cladistic analysis, Westrop et al. (1996) placed Onymagnostus in synonymy with Ptychagnostus. Peng \& Robison (2000) dispute the work of Westrop etal. and return Onymagnostus to Lejopyge. Shergold \& Laurie (1997) maintained Onymagnostus as a separate genus. A detailed analysis of this matter is outside the scope of this paper, but we would suggest that Onymagnostus does not belong in Lejopyge. We would prefer to retain Onymagnostus as a separate genus.

\section{Lejopyge laevigata (Dalman, 1828) PI. 1L-M,P-S; PI. 2C}

\section{Synonymy}

See Peng \& Robison (2000).

\section{Material}

Two poorly preserved complete agnostoids, five poorly preserved cephala and four reasonably well-preserved pygidia are available. Specimens UTGD 125331, 125332a, b, 125335a, b, 125336-125338, 125441.

\section{Remarks}

The available cephala are poorly preserved. The very posterior of the glabella is outlined by shallow axial furrows; the basal lobes are very small. The pygidia, which are better preserved, have a narrow, shallow border furrow and a narrow, flat border. The anterior part of the axis is outlined by shallow furrows which fade posteriorly, becoming effaced about the position of the F2 furrow. There is a low node on M2; posterolateral spines are absent.

These specimens are assigned to Lejopyge based on the narrow pygidial border, the lack of pygidial spines and the high degree of effacement, suggesting affiliation with either L. laevigata or $L$. calva, with the former being preferred.

\section{Family SPINAGNOSTIDAE Howell, 1935a Genus Hypagnostus Jaekel, 1909}

Hypagnostus Jaekel 1909: 399; Kobayashi 1939: 122; Lermontova 1940: 129; Westergărd 1946: 43 (part); Ivshin 1953: 17; Howell 1959: 184; Öpik 1961:57; Robison 1964: 529 (part); Lu et al. 1965: 44; Öpik 1967: 82; Palmer 1968: 31 (part); Jago 1976a: 140 (part); Öpik 1979: 65; Lu \& Lin 1989: 105; Shergold et al. 1990: 43; Jago \& Webers 1992: 106; Westrop et al. 1996: 822; Shergold \& Laurie 1997: 356; Peng \& Robison 2000: 60.

Cotalagnostus Whitehouse 1936: 92; Kobayashi 1939: 129; Lermontova 1940: 129; Westergård 1946: 53; Howell 1959: 184; Robison 1964: 528; Shergold et al. 1990: 43; Shergold \& Laurie 1997: 356.

\section{PLATE 1}

(A-K) Goniagnostus nathorsti (Brogger 1878): (A) UTGD125320a complete specimen, holotype, silicone rubber cast of external mould, $\times 8$; (B) UTGD125321b complete specimen, internal mould, $\times 8$; (C) UTGD125322 complete specimen, internal mould, $\times 5$; (D) UTGD125323 complete specimen, internal mould, $\times 8$; (E) UTGD125324 complete specimen, silicone rubber cast of external mould, $\times 10 ;(F)$ UTGD125325a complete specimen, silicone rubber cast of external mould, $\times 8$; (G) UTGD125326b complete specimen, internal mould, $\times 10$; (H) UTGD125327 complete specimen, internal mould, $\times 10$; (I) UTGD 125328 disarticulated cephalon and pygidium, internal mould, $\times 6 ;$ (J) UTGD125329 pygidium, internal mould, X6; (K) UTGD125330 complete specimen, silicone rubber cast of external mould, $\times 8$.

(L-M, P-S) Lejopyge laevigata (Dalman 1828): (L) UTGD125331 cephalon, internal mould, $\times 6$; (M) UTGD125332b pygidium, internal mould, $\times 10 ;(P)$ UTGD125335b poorly preserved complete specimen, internal mould, $\times 10 ;(Q)$ UTGD125336 cephalon with thoracic segments, internal mould, $\times 15$; (R) UTGD125337 pygidium, internal mould, $\times 15$; (S) UTGD125338 pygidium, internal mould, $\times 7$.

$(N, O)$ Lisogoragnostus sp.: (N) UTGD125333 complete specimen, internal mould, $\times 20$; (O) UTGD 125334 partial pygidium, silicone rubber cast of external mould, $\times 15$.

Specimens figured in $L$ and $S$ come from Locality 2; all others come from Locality 1. 

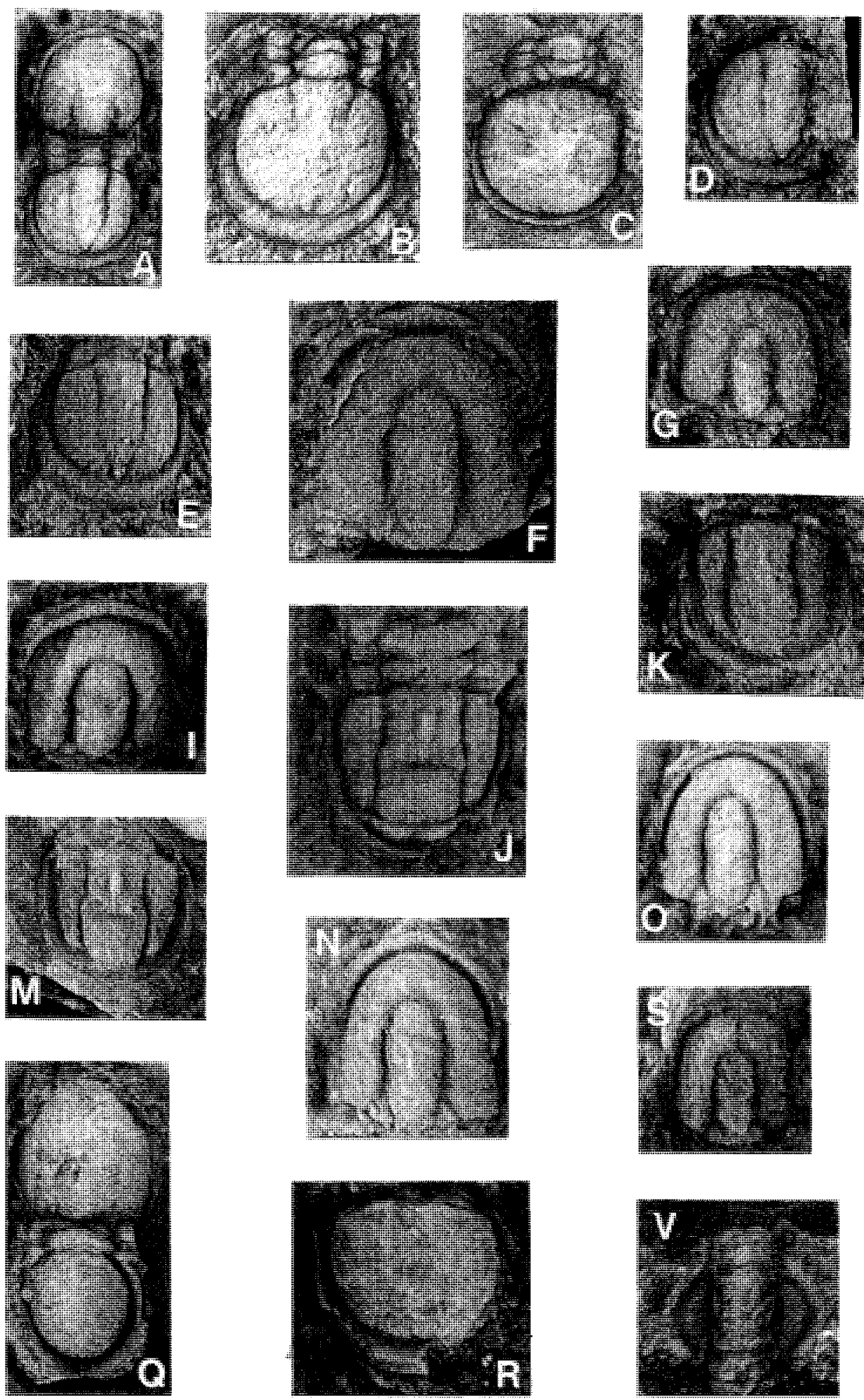
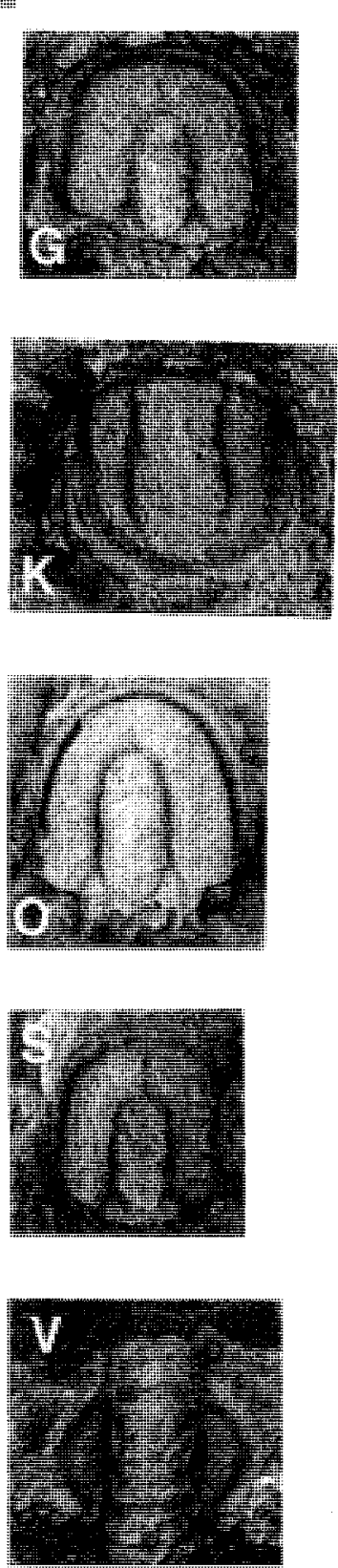
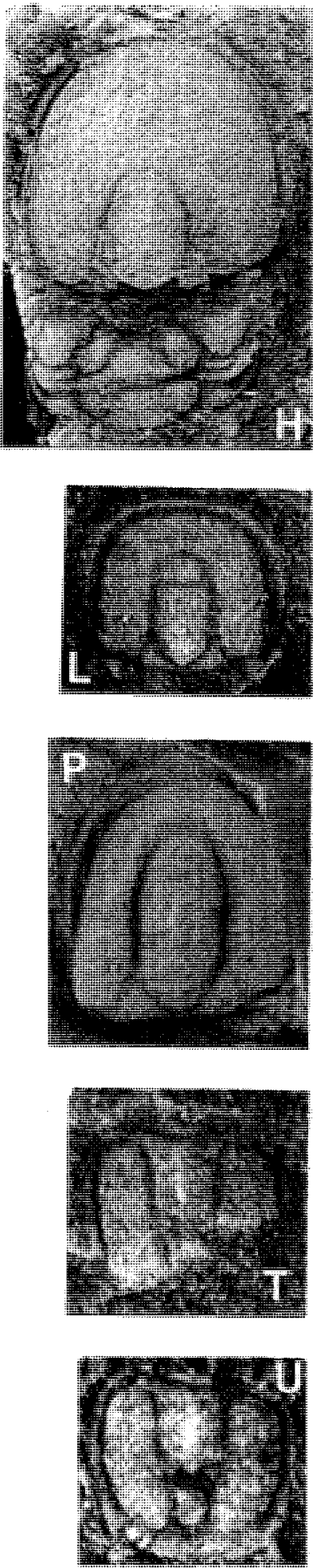
Type species

Agnostus parvifrons Linnarsson 1869: 82, pl.2, figs 56, 57.

\section{Diagnosis}

See Shergold \& Laurie (1997: 356), with the amendment that the F3 glabellar furrow may be effaced as may be the posterior parts of the axial furrows of the pygidium.

\section{Discussion}

Öpik (1979: 71) stated that although many authors had followed Westergård (1946: 44) in placing Tomagnostella in synonymy with Hypagnostus, he regarded Tomagnostella as a separate genus, a move supported by Robison (1988: 57), Lu \& Lin (1989: 108), Shergold et al. (1990: 44), Jago \& Webers (1992: 106), Shergold \& Laurie (1997: 358) and herein.

The generally accepted concept of Cotalagnostus is that it is similar to Hypagnostus except that the $\mathrm{F} 3$ glabella furrow is effaced, as may be the posterior parts of the pygidial axial furrows. Many of the pygidia of Cotalagnostus lens and $C$. lens claudicus as illustrated by Westergård 1946 (pls 6, 7) and Hutchinson 1962 (pl. 6) are indistinguishable from those of Hypagnostus. Westergard (1946) and Robison (1964) considered Cotalagnostus evolved from Hypagnostus by effacement of furrows. Westrop et al. (1996) concluded that the difference between the two genera, i.e. the presence of a distinct F3 furrow on the cephalon of Hypagnostus, was arbitrary and regarded Cotalagnostus as a junior synonym of Hypagnostus. Shergold \& Laurie (1997) maintained the separation of the two genera. Peng \& Robison (2000) disputed the placement of Cotalagnostus in synonymy with Hypagnostus, on the grounds that Cotalagnostus is differentiated by the effacement of F3 and the greater effacement of its axial furrows on both the cephalon and pygidium. We accept Cotalagnostus as a junior synonym of Hypagnostus on the grounds given by Westrop et al. (1996) and because, as noted above, it is difficult to distinguish the pygidia of the two genera.

\section{Hypagnostus trali sp. nov. PI. 2A, B, D, E}

\author{
Derivation of name \\ Anagram of Trial.
}

\section{Material}

The holotype, a complete specimen (UTGD125339), a pygidium with thorax attached (UTGD 125340) and two pygidia (UTGD 125342-43) are assigned to this species.

\section{Holotype}

Complete specimen UTGD125339 (Pl. 2A) is selected as holotype.

\section{Diagnosis}

Both cephalon and pygidium have unconstricted acrolobes, narrow borders and narrow, shallow border burrows. Posterior part of glabella outlined by shallow axial furrows. Narrow pygidial axis extends almost full length of acrolobe; F1 and F2 effaced. Terminal axial node present.

\section{Description}

Complete specimen $3.5 \mathrm{~mm}$ long. Acrolobes unconstricted. Cephalon about as wide as long. Narrow, shallow border furrow; narrow convex border. Small basal lobes. Broadly rounded glabellar posterior. Posterior part of glabella outlined by shallow axial furrows which extend almost 0.4 length of cephalon to a position just short of where F3 would be. Pygidium about as wide as long. Narrow, shallow border furrow; narrow, convex border widens posteriorly. Narrow pygidial axis extends almost full length of acrolobe; slight constriction at position of M2. F1, F2 effaced. Terminal axial node present.

\section{Discussion}

The pygidial axis of trali is narrower and extends further to the posterior than in $H$. lens or the subspecies $H$. lens claudicans (Westergård 1946). The pygidium of H. confusus is more effaced than that of trali, and where the outline of the axis of confusus can be seen (Westergård 1946: pl.7, figs $14,16,19)$, it is shorter than that of trali. H. laevus is

PLATE 2

( $A, B, D, E)$ Hypagnostus trali sp. nov.: (A) UTGD125339 complete specimen, holotype, internal mould, $\times 10 ;(B)$ UTGD125340a pygidium with thorax attached, silcone rubber cast of external mould, $\times 12$; (D) UTGD125342 small pygidium, silicone rubber cast of external mould, $\times 20 ;(E)$ UTGD125343 pygidium, internal mould, $\times 7$.

(C) Lejopyge laevigata (Dalman 1828). UTGD125341 pygidium and thoracic segments, silicone rubber cast of external mould, $\times 10$.

(F,I,J,M-P) Oidalagnostus changi Lu 1964: (F) UTGD125344 cephalon internal mould, X8; (I) UTGD125347 cephalon, internal mould, $\times 6 ;(J)$ UTGD125348 pygidium and thoracic segments, internal mould, $\times 7 ;(M)$ UTGD125351 pygidium, internal mould, $\times 5$; (N) UTGD125352 cephalon, internal mould, $\times 10$; (O) UTGD125353 cephalon, internal mould, $\times 8$; (P) UTGD125354 cephalon, silicone rubber cast of external mould, $\times 10$.

(G,K,L) Ammagnostus laiwuensis (Lorenz 1906): (G) UTGD125345 cephalon, internal mould, $\times 5$; (K) UTGD125349 pygidium, internal mould, X6; (L) UTGD 125350 cephalon, internal mould.

(H) Hypagnostus brevifrons (Angelin 1851) UTGD125346 cephalon and thoracic segments, internal mould, $\times 8$.

(Q) Glaberagnostus sp. UTGD1253556 complete specimen, internal mould, $\times 6$.

(R) Valenagnostus sp. UTGD125356 partial pygidium, internal mould, $\times 15$.

(S) Agnostoid gen. et sp. indet. UTGD125357 cephalon, internal mould, $\times 15$.

(T,U) Clavagnostus cf. repandus (Westergard in Holm \& Westergard 1930): (T) UTGD125358 partial pygidium, internal mould, $\times 8$; UTGD125359 pygidium, internal mould, $\times 10$.

(V) Bathyuriscus (?) sp. UTGD125360 partial cranidium, internal mould, $\times 10$.

Specimens figured in $A-D, I, J, N-R, T$ and $U$ come from Locality 1 ; those figured in $E-H, K-M, S$ and $V$ come from Locality 2. 
much more effaced than trali (Robison 1964: pl.80, figs 17-28). The pygididial axis of Cotalagnostus sp. 1 of Egorova et al. (1982: pl.14, fig. 14) extends to the posterior of the acrolobe as in trali but is wider than that of trali. The pygidium of trali is similar to that of $H$. bippalus Öpik 1961; however, the cephalon of bippalus is quite different.

\section{Hypagnostus brevifrons (Angelin, 1851) PI. $2 \mathrm{H}$}

\section{Synonymy}

See Peng \& Robison (2000).

\section{Material}

One cephalon with attached thoracic segments (UTGD 125346)

\section{Remarks}

As noted by Peng \& Robison (2000) and other authors, cephala of $H$. brevifrons and $H$. parvifrons are difficult to distinguish. However, when compared with previously illustrated material, this cephalon appears to fit better into H. brevifrons.

\section{Genus Lisogoragnostus Rozova in Lisogor, Rozov \& Rozova, 1988}

\section{Synonymy}

See Peng \& Robison (2000).

\section{Type species}

Lisogoragnostus kalisae Rozova in Lisogor et al. (1988: 64, pl. 5, fig. 9)

\section{Diagnosis}

See Peng \& Robison (2000: 64) with the amendment that the pygidium may have a narrow border.

\section{Remarks}

Peng \& Robison (2000) discussed the genus comprehensively. The pygidium described by Jago (1976a: pl. 26, fig. 15) as Agnostid, gen. et sp. indet. no. 1 figured from $S t$ Valentines Peak, Tasmania, should be included in Lisogoragnostus. The explanation for plate 26 , figure 15 in Jago (1976a) is incorrect in that it states that the specimen is Agnostid, gen. et sp. indet. no. 2.

\section{Lisogoragnostus sp. PI. $1 \mathrm{~N}, \mathrm{O}$}

\section{Material}

One almost complete specimen (UTGD 125333) and a partial pygidium (UTGD 125334). Neither specimen is well preserved.

\section{Description}

Both available specimens small. Complete specimen (pl. 1N) length of $1.5 \mathrm{~mm}$. Acrolobes unconstricted. Cephalon about as wide as long. Very narrow, shallow border furrow; very narrow border. Very small basal lobes. Shallow axial furrow effaced forwards of F3. F3 very shallow; concave anteriorly.
Posteroglabella has length about $0.4-0.45$ of glabella. Pygidium about as wide as long. Narrow, shallow border furrow; narrow, flat border. Narrow, shallow axial furrow. Axis has length about $0.6-0.65$ and width about 0.5 of pygidium. Axis parallel-sided for about 0.75 of length from where it narrows to angulate posterior. F1, F2 effaced. Smooth pleural fields.

\section{Remarks}

These specimens differ from previously described species of Lisogoragnostus by the presence of a distinct pygidial border. However, the preservarion is not good enough to just ify the erection of a new species. The Trial Ridge specimens are probably closest to L. hybus Peng \& Robison (2000: fig.47). However, the cephalon of L. hybus is more elongated than the Trial Ridge specimens. The pygidial axis of the Trial Ridge species appears to be angulate in a manner similar to the pygidia described and figured by Rasetti (1967: 38, pl. 10, figs 22-26) as Agnostida, pygidium no. 1, which belong in Lisogoragnostus (Peng \& Robison 2000). However, preservation of our specimens makes it difficult to be certain about this matter. The anteroaxis of the Trial Ridge specimens is more parallel-sided than in the specimen of Lisogoragnostus illustrated by Jago (1976a: pl. 26, fig. 15) as Agnostid gen. et sp. indet. no. 1 .

\section{Family AMMAGNOSTUS Öpik, 1967 Genus Ammagnostus Öpik, 1967}

\section{Synonymy}

See Peng \& Robison (2000: 25).

Type species

Ammagnostus psammius Öpik 1967: 139, pl. 55, fig. 3; pl. 66, figs 1-4; text fig. 40.

\section{Diagnosis}

See Peng \&Robison (2000: 25)

\section{Ammagnostus laiwuensis (Lorenz, 1906) PI. 2G, K, L}

\section{Synonymy}

See Peng \& Robison (2000: 27).

Material

Three cephala and one pygidium. Specimens UTGD $125345,125349,125350$

\section{Diagnosis}

See Peng \& Robison (2000: 29).

\section{Remarks}

These specimens fit Peronopsis ekip of Jago (1976a), which was placed in synonymy with Ammagnostus laiwuensis (Lorenz, 1906) by Peng \& Robison (2000). This synonymy is accepted herein. 


\section{Family DIPLAGNOSTIDAE Whitehouse, 1936 \\ Subfamily OIDALAGNOSTINAE Öpik, 1967 Genus Oidalagnostus Westergård, 1946}

Synonymy

See Peng \& Robison (2000).

Type species

Oidalagnostus trispinifer Westergård (1946: 65, pl. 9, figs 47).

\section{Diagnosis}

See Peng \& Robison (2000).

\section{Discussion}

Robison (1988: 37) discussed Oidalagnostus and related genera in some detail and concluded that Ovalagnostus Lu 1974 (type species, O. changi Lu in Lu et al. 1974) and Tasagnostus Jago 1976 (type species, T. debori) are junior synonyms of Oidalagnostus Westergård 1946. Lu \& Lin (1989: 81) placed Tasagnostus in synonymy with Ovalagnostus, which they retained as a separate genus from Oidalagnostus. Peng \& Robison (2000) included Ovalagnostus as a junior synonym of Oidalagnostus, as did Shergold et al. (1990), Shergold \& Laurie (1997) and the present authors. Peng \& Robison (2000) place Tasagnostus compani of Jago (1976a) questionably in synonymy with Oidalagnostus changi. Certainly compani and changi are quite close and belong in the same genus, Oidalagnostus, but better specimens of both species are required before a final assessment is made. Peng \& Robison (2000) included Tasagnostus as a junior synonym of Diplagnostus. However, the two genera are clearly differentated on the basis of the structure of the pygidial axis and the glabellar anterior. Rushton (1978:264) pointed out that genera such as Oidalagnostus, Tasagnostus, Cristagnostus, Oedorhachis, Linguagnostus and Dolichagnostus are best distinguished in the features of the pygidial axis.

Shergold et al. (1990) placed Tasagnostus in the Diplagnostinae along with Diplagnostus, Baltagnostus, Dolichagnostus, Linguagnostus and Oedorhachis, with Iniospheniscus being included questionably in the Diplagnostinae. They suggested that Diplagnostus, Linguagnostus, Dolichagnostus and Tasagnostus fit into a tight morphological group characterised by a zonate pygidium in combination with an axiolobate or only slightly modified axiolobate condition, frequently with a transverse depression on the anterior of the posterior pygidial lobe and an often sulcate anterior glabellar lobe. Shergold \& Laurie (1997) added Acadagnostus to the Diplagnostinae.

Shergold et al. (1990) and Shergold \& Laurie (1997) placed Oidalagnostus, along with Cristagnostus, in the Oidalagnostinae and characterised the subfamily as having a zonate pygidium, but with a gap in the pygidial collar. They stated that the anteroaxis of the pygidium comprises three segments, that the posterior lobe is subquadrate and extends to the pygidial collar, and that a third, centrally placed marginal spine is present. They suggested that the major features in the phylogeny of Oidalagnostus and Cristagnostus are the separation of the anterior portion of the posterior lobe of the axis as the third segment of the anteroaxis and the presence of lateral bosses as appendages of this third segment.
As revised above, the only two species of Tasagnostus are T. debori Jago 1976a and Tasagnostus sp. Jago $1976 \mathrm{~b}$ (pl. 2, fig. 18). It is possible that Tasagnostus is ancestral to Oidalagnostus, with the best known species, $T$. debori, occurring in either the L. laevigata I or II Zones on the northern Australian biochronological scale. O. compani from St Valentines Peak, Tasmania, is from the L. laevigata III Zone or the Damesella torosa-Ascionepea janitrix Zone. However, in Queensland Oidalagnostus ranges from the $L$. laevigata II Zone through to the lower part of the Acmarhachis quasivespa Zone (Öpik 1967: table 4). Öpik (1967: 134) suggested that $O$. trispinifer is found in the Glyptagnostus stolidotus Zone of Tasmania. However, to the best of the authors' knowledge, the youngest known Oidalagnostus from Tasmania is from the Brewery Junction Formation at Dundas, where it is in either the Erediaspis eretes or Acmarhachis quasivespa Zone (Jago 1972).

\section{Oidalagnostus changi Lu, 1964 PI. 2F, I, J, M-P}

\section{Synonymy}

See Peng \& Robison (2000: 56).

\section{Material}

Nine cranidia and four pygidia, three of which have attached thoracic segments. Illustrated specimens UTGD 125344 , 125347-125348, 125351-125354.

\section{Diagnosis}

See Peng \& Robison (2000: 57).

\section{Remarks}

These specimens are similar to Oidalagnostus changi as illustrated by Peng \& Robison (2000: fig. 43). The cranidia show some variation. The anterior margin may show a distinct anterior angularity (pl. 2O), may be quite smooth (pl. 2I) or have a slight angularity (pl. 2F, N). The depth of the transverse glabellar furrow is variable, as is the shape of the glabellar posterior. In the pygidium the pleural fields are slightly pitted. The collar is separated from the axis by a shallow, narrow furrow; the knobs on the collar are well developed. There is a well-developed furrow between the collar and the pygidial border.

Family CLAVAGNOSTIDAE Howell, 1937 Subfamily CLAVAGNOSTINAE Howell, 1937 Genus Clavagnostus Howell, 1937

\section{Type species}

Agnostus repandus Westergård in Holm \& Westergård, (1930:13, pl.4, figs 11, 12 only).

Diagnosis

See Jago \& Daily (1974: 97).

\section{Clavagnostus cf. repandus (Westergård in Holm \& Westergård 1930) PI. 2T, U}

Material

Two small, poorly preserved pygidia, UTGD 125358-59. 

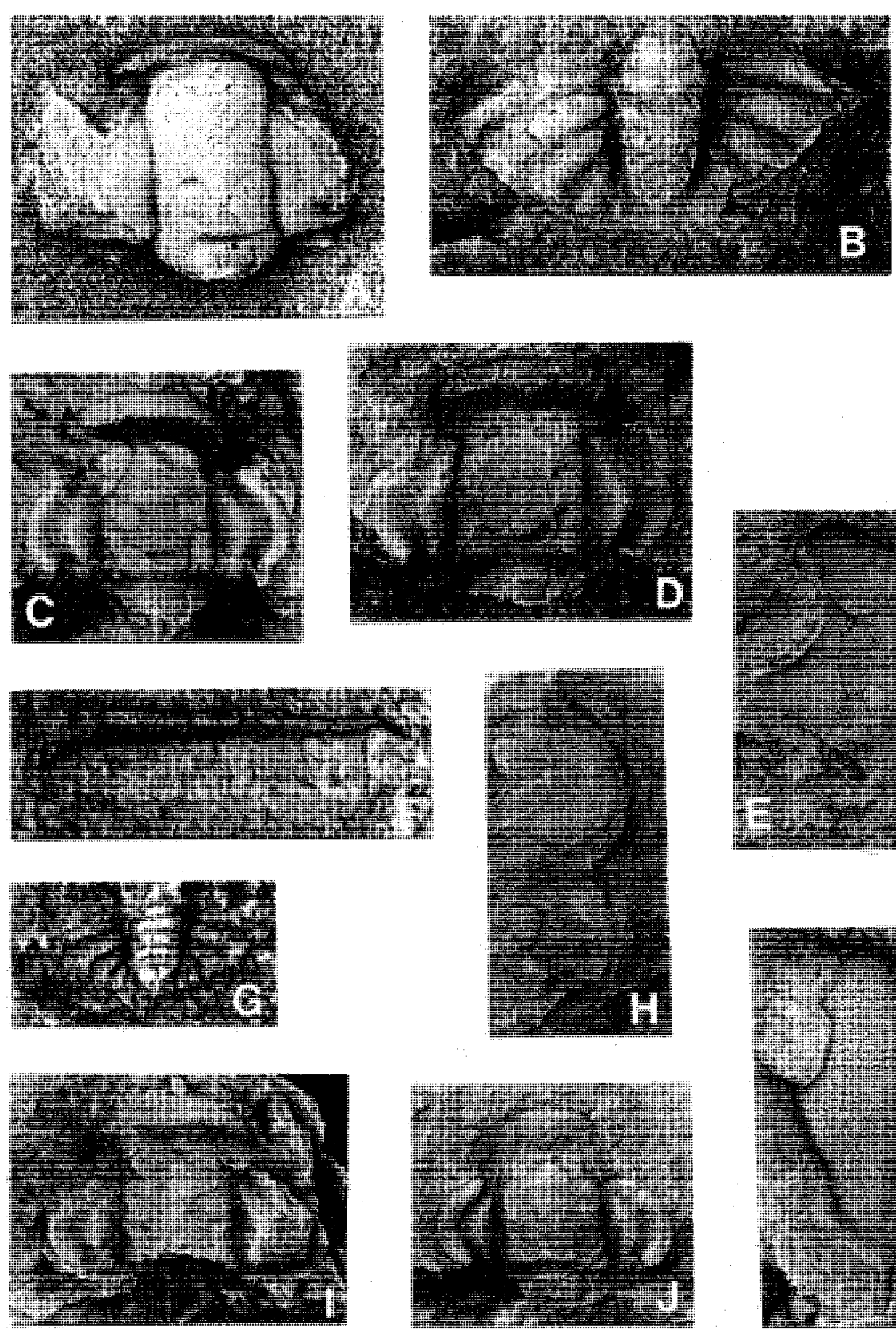
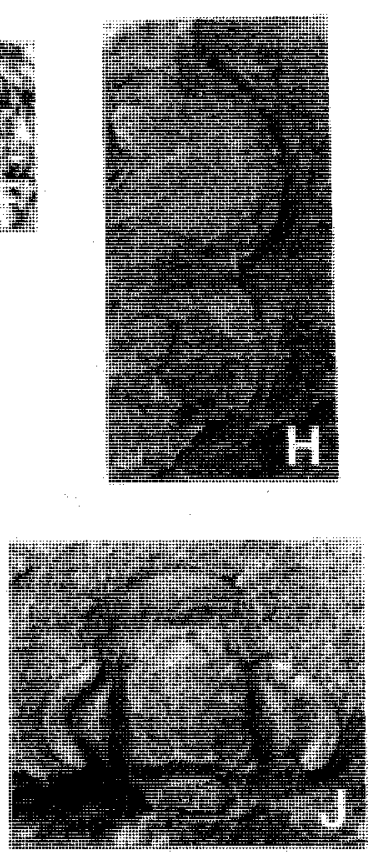
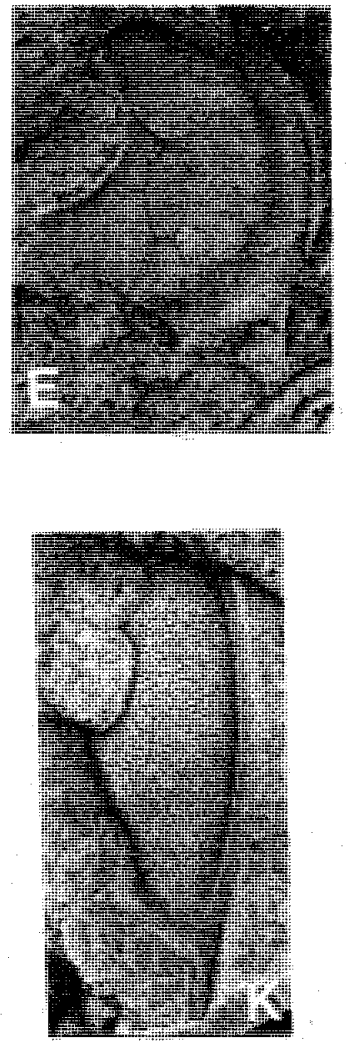
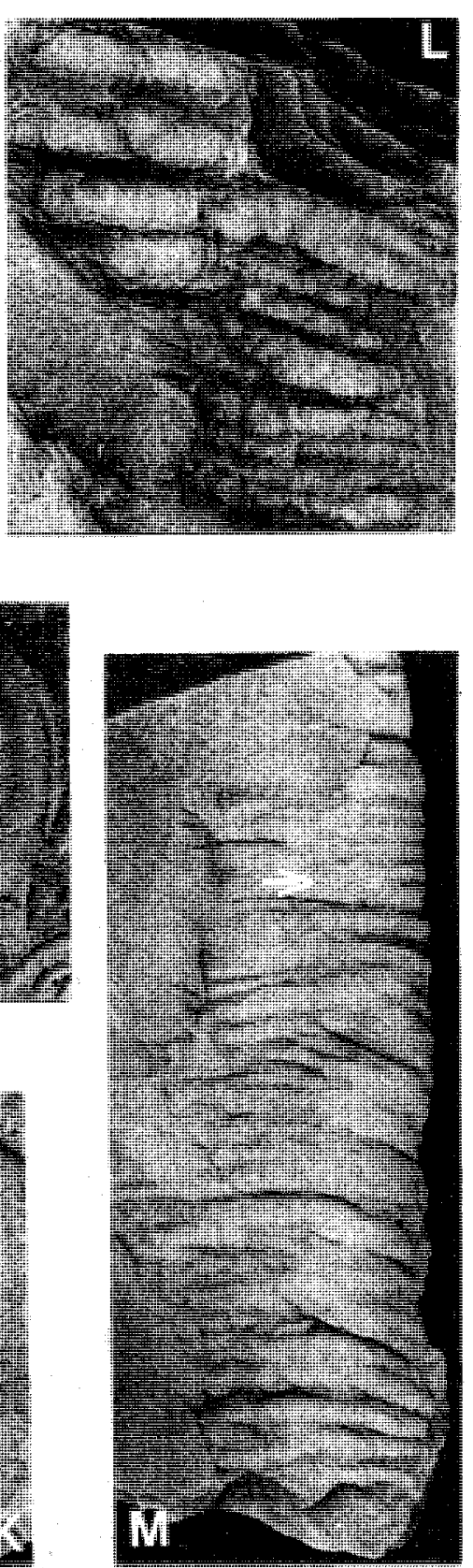

\section{PLATE 3}

(A, G) Amphoton sp.: (A) UTGD125361a cranidium, silicone rubber cast of external mould, $\times 4$; (G) UTGD125367 pygidium, internal mould, $\times 10$.

(B) Fuchouia $s p$. UTGD125362 pygidium, silicone rubber cast of external mould, $\times 5$.

(C-E, H-J) Proasaphiscidae gen. et sp. indet.: (C) UTGD125363 cranidium, internal mould, $\times 4$; (D) UTGD125364 cranidium, internal mould, $\times 6 ;$ (E) UTGD125365 right librigena, silicone rubber cast of external mould, $\times 8$; (H) UTGD125368 right librigena, internal mould, X5; (I) UTGD125369 partial cranidium, internal mould, X3; (J) UTGD125370 cranidium, internal mould, $x 6$.

(F, K) Papyriaspidae gen. et sp. indet.: (F) UTGD125366 partial thoracic segment, silicone rubber cast of external mould, $\times 10$; (K) UTGD125371 right librigena, silicone rubber cast of external mould, $\times 5$.

$(L, M)$ Trace fossils: (L) UTGD125372 internal mould, $\times 2$; (M) UTGD125373b internal mould, $\times 1$. The arrow points to a small complete specimen of Goniagnostus nathorsti resting on the tracks.

Specimens figured in $A, F, G$, and $K-M$ come from Locality 1 ; those figured in $B-E$ and $H-J$ come from Locality 2. 


\section{Remarks}

These pygidia are similar to $C$. repandus as described and illustrated by Westergård (1946), and in particular to the pygidium figured by Westergård (1946: pl.4, fig.22) and refigured by Jago \& Daily (1974: 11, fig.4).

\section{Family INCERTAE SEDIS \\ Genus Glaberagnostus Romanenko, 1985}

Type species

Glaberagnostus altaicus Romanenko 1985: 57, pl. 5, figs 57.

\section{Diagnosis}

See Peng \& Robison (2000: 90).

\section{Glaberagnostus sp. PI. 2Q}

\section{Material}

One almost complete specimen, UTGD 125355a, b.

\section{Description}

Specimen length, $7.0 \mathrm{~mm}$. Cephalon almost completely effaced; only very posterior of glabella distinguished. Border appears absent. Position of any glabellar node indeterminate due to preservation. Pygidium with wide border and border furrow; low centrally placed node about 0.2 of distance from anterior to posterior of acrolobe.

\section{Genus Valenagnostus Jago, 1976a}

Type species

Agnostus nudus Beyrich var. marginata Brøgger 1878: 73, pl. 6, fig. 3 .

Diagnosis

See Jago (1976a: 142).

\section{Valenagnostus sp. Pl. 2R}

Material

Two small, poorly preserved pygidia. Illustrated specimen, UTGD 125356.

\section{Remarks}

The effaced acrolobe, wide pygidial border and suggestion of a terminal axial node suggest affiliation with Valenagnostus.

Agnostoid gen. et sp. indet.

$$
\text { PI. } 2 S
$$

Material

Five cephala. Illustrated specimen, UTGD 125357.

\section{Description}

Narrow border; border furrow of moderate width. Glabella
0.6-0.7 length of cephalon. F1, F2 short, shallow; F3 shallow, straight. Posteroglabella length about 0.7 that of glabella. Glabellar posterior broadly rounded. Shallow preglabellar median furrow extends to anterior border. Small basal lobes confluent behind glabella. Smooth cheeks.

\section{Remarks}

These small cephala are not assigned to any particular genus. They may belong in Agnostus or a related genus.

\section{Family DOLICHOMETOPIDAE Walcott, 1916 Genus Amphoton Lorenz, 1906}

\author{
Synonymy \\ See Zhang \& Jell (1987: 62).
}

Type species

Amphoton steinmanni Lorenz (1906: 89, pl. 4, figs 15-17).

\section{Amphoton sp. \\ PI. 3A,G}

\section{Material}

One well-preserved cranidium is available both as the internal and external mould (UTGD $125361 \mathrm{a}, \mathrm{b}$ ); a small pygidium (UTGD 125367) may belong in the same species.

\section{Description}

Amphoton with shallow occipital furrow; base of what appears to have been a strong occipital spine preserved. Lateral glabellar furrows entirely effaced. Shallow axial furrows. Glabellar anterior almost straight. Anterior border of moderate width; shallow anterior border furrow. Palpebral areas of fixigenae gently convex. Shallow palpebral furrows. Narrow posterolateral limbs; well-developed posterior border furrow. Pygidial axis stops just short of posterior margin. Axis of four annulations plus terminus; four pairs of pleural furrows. No distinct border.

\section{Remarks}

The cranidium shows some similarities with Amphoton deois, although the anterior border of deois is a little wider, the palpebral areas of the fixed cheeks are a little narrower, and the anterior sections of the facial suture of deois do not diverge as much as those of the Trial Ridge form.

The characters of the pygidium, including the absence of a distinct border, suggest affiliation with Fuchouia rather than Amphoton (e.g. Zhang \& Jell 1987: 67). Although it is quite possible that the two specimens described here under Amphoton sp. belong in separate species or even separate, but related genera, they are placed together in open nomenclature until more material is obtained.

\section{Genus Fuchouia Resser \& Endo in Kobayashi 1935}

\author{
Synonymy \\ See Zhang \& Jell (1987: 66).
}

\section{Type species}

Bathyuriscusmanchuriensis Walcott (1911:97, pl. 16, fig. 4). 


\section{Fuchouia sp.}

PI. 3B

\section{Material \\ One pygidium, UTGD 125362}

\section{Description}

Although posterior of axis is poorly preserved there appear to be four axial annulations plus a terminus. Four pairs of pleural furrows, plus at least two pairs of faintly developed interpleural furrows. Very narrow border.

\section{Remarks}

The presence of the interpleural furrows and a very narrow border indicates that this pygidium belongs in Fuchouia rather than Amphoton (Zhang \& Jell 1987: 67).

\section{Genus Bathyuriscus Meek, 1873}

Type species

Bathyurus(?) haydeni Meek (1873: 484).

\section{Diagnosis}

See Robison (1964: 534).

\section{Bathyuriscus (?) $\mathrm{sp}$ PI. 2V}

\author{
Material \\ One partial cranidium, UTGD125360.
}

\section{Remarks}

This specimen is questionably assigned to Bathyuriscus as defined by Robison (1964: 534). In Bathyuriscus the glabella expands anteriorly, but this feature is not clear on the available specimen. Robison's diagnosis stated that the palpebral lobes have a length one-third that of the cranidium. However, although a complete cranidium is not available, it is probable that the palpebral lobes of the Tasmanian specimens are considerably longer. When compared with Bathyuriscus fimbriatus Robison 1964, Bathyuriscus (?) sp. has wider fixigenae.

\section{Family PROASAPHISCIDAE Chang, 1963 Proasaphiscidae, gen. et $\mathrm{sp}$. indet. PI. 3C-E, $\mathrm{H}-\mathrm{J}$}

\section{Material}

Six partial cranidia and several librigenae. Illustrated specimens, UTGD 125363-125365; 125368-125370.

\section{Description}

Large, convex subrectangular glabella about $0.75-0.8$ cephalic length and about 0.43 cranidial length. Glabella tapers slightly forwards to a truncated front at anterior border furrow. Deep axial furrows. Lateral glabellar furrows very poorly defined. Shallow occipital furrow; occipital ring narrows abaxially. Long, crescentic palpebral lobes extend from just forwards of occipital furrow to about three- quarters length of glabella. Anterior ends of palpebral lobes close to axial furrows. Wide palpebral furrows. Palpebral areas of fixigenae gently convex. Gently convex anterior border furrow. Anterior sections of facial suture diverge slightly; posterior sections diverge markedly. Wide posterior border furrow. Gently convex librigena with shallow border furrow. Moderately wide border widens posteriorly and extends into long genal spine.

\section{Remarks}

These specimens belong to a new genus of the Proasaphiscidae that is also found in other late Middle Cambrian faunas from Tasmania, at Riana, Native Track Tier and StValentines Peak (Laurie et al. 1995). Much better preserved, and more complete specimens, are known from these localities (Bao 1995).

\section{Family PAPYRIASPIDIDAE Whitehouse, 1939}

\author{
Papyriaspididae gen. et $\mathrm{sp}$. indet. \\ PI. 3F, K
}

\section{Remarks}

A single well-preserved partial librigena (UTGD 125371) and a partial thoracic segment (UTGD 125366) may belong in a single genus of the Papyriaspididae. It has a narrow border and part of a well-developed genal spine. A very welldeveloped and prominent caecal pattern radiates out from the shallow palpebral furrow. The librigena is similar to that figured by Öpik (1961: pl.15, fig. 6) for Pianaspis sors (Öpik).

\section{Trace Fossils \\ PI. 3L, M}

\section{Remarks}

Two sets of what appear to be trilobite resting places occur at Locality 1. The larger one ( $\mathrm{Pl} .3 \mathrm{M}$ ) has a length of almost $100 \mathrm{~mm}$, while the smaller one (Pl. 3L) has a length of almost $30 \mathrm{~mm}$. Both are incomplete. Given that only two specimens are available, it is difficult to assign these specimens to any particular ichnogenus, but they appear to be related to Rusophycus. One of the specimens (Pl. 3M) has a small specimen of Goniagnostus nathorsti resting on it.

\section{ACKNOWLEDGEMENTS}

These fossils were collected by AVB as part of the regional mapping programme of the Tasmanian Department of Resources and Energy. Logistic support from theDepartment is acknowledged. The assistance of the former curators of the collections of the School of Earth Sciences, University of Tasmania, Penny Williamson and Kathi Stait, is gratefully acknowledged. The comments of two anonymous referees as well as those of the former editor, Dr M.R.Banks, improved the paper. R.A. Robison (University of Kansas) is thanked for constructive comments on an earlier version of this paper. JBJ was supported by a grant from the Australian Research Council. 


\section{REFERENCES}

ANgelin, N.P., 1851: Palaeontologia Suecica, pars 1: Iconographia crustaceorum formationis transitionis. Weigel, Lund: $24 \mathrm{pp}$.

BAO JINSONG, 1995. Some Middle and Late Cambrian trilobites from western and northwestern Tasmania. Unpubl. MSc thesis, Univ. S. Aust.: 196 pp.

BRøGGER, W.C., 1878: Om paradoxideskifrene ved Krekling. Nyt Mag. Naturvid. 24: 18-88.

Brown, A.V., McClenaghan, M.P., Turner, N.J., Baillie, P.W., McClenaghan, J., Lennox, P. \& Williams, P.R., 1982 HUNTLEY. Geol. Atlas 1:50 000 series. Sheet $73(8112 \mathrm{~N})$. Department of Mines, Tasmania.

Brown, A.V., McClenaghan, M.P., Turner, N.J., Baillie, P.W. MCClenaghan, J. \& Calver, C.R., 1989: HUNTLEY. Geol. Atlas 1:50 000 series. Explan. rep. Sheet $73(8112 \mathrm{~N})$. Department of Mines, Tasmania: $109 \mathrm{pp}$.

Chang Wentang. See Zhang Wentang.

Corbett, K.D., 1970: Sedimentology of an upper Cambrian flysch-paralic sequence (Denison Group) on the Denison Range, south-west Tasmania. Unpubl. PhD thesis, Univ. Tasm.: 207 pp.

DaILY, B. \& JAGO, J.B., 1975: The trilobite Lejopyge Hawle and Corda and the middle-upper Cambrian boundary. Palaeontology 18: 527-550.

Dalman, J.W., 1828: Nya Svenska Paleader. Kongl. Sv. Vet. Acad., Arsberattelser om nyare zoologiska arbeten och upptackter: 138 pp.

Egorova, L.I., Shabanov, Y.Y., Pegel, T.V., Savitsky, V.E., Suchov, S.S. \& Chernysheva, N.E., 1982: [Maya Stage of the type locality (Middle Cambrian of Siberian platform)]. Trudy Akad. Nauk SSSR, Minist. Geol., Mezhvedorn. Stratigr. Kom. SSSR 8: 1-146 (in Russian).

Hawle, I. \& CoRdA, A.J.C., 1847: Prodom einer Monographie der böhmischen Trilobiten. Abh. K. böhm. Ges. Wiss. 5: 1-176.

Holm, G. \& Westergßrd, A.H., 1930. A Middle Cambrian fauna from Bennett Island. Mem. Acad. Sci. l'URSS 21(8): $1-25$.

Howell, B.F., 1935a: New Cambrian agnostian trilobites from Vermont. J. Paleont. 9: 218-221.

Howell, B.F., 1935b: Some New Brunswick Cambrian agnostians. Bull. Wagner Free Inst. Sci.10(2): 13-16.

Howell, B.F., 1937: Cambrian Centropleura vermontensis fauna of northwestern Vermont. Bull. Geol. Soc. Am. 48: 1147 1210 .

Howell, B.F., 1959: Agnostidae, Eodiscidae and Pagetiidae. In Moore, R.C. (Ed.): TREATISE ON INVERTEBRATE PALEONTOLOGY, PART O,ARTHROPODA 1. University of Kansas Press and Geological Society of America: 560 pp.

Hutchinson, R.D., 1962: Cambrian stratigraphy and trilobite faunas of southeastern Newfoundland. Bull. Geol. Surv. Can. 88: $1-156$

Ivshin, N.K., 1953: [Middle Cambrian trilobites of Kazakhstan, Part 1]. Akad. Nauk. Kazakhstan SSR, Inst. Geol. Nauk, Alma-Ata: 226 pp. (in Russian).

JAekel, O., 1909: Über die Agnostiden. Z. dt. Geol. Ges, 61: $380-401$.

JAGO, J.B., 1972: Biostratigraphic and taxonomic studies of some Tasmanian Cambrian trilobites. Unpubl. PhD thesis, Univ. Adelaide: 448 pp.

JAGO, J. B., 1973: Cambrian agnostid communities in Tasmania. Lethaia 6: 405-421.

JAGO, J.B., 1976a: Late Middle Cambrian agnostid trilobites from north-western Tasmania. Palaeontology 19: 133172 .

JAGO, J.B., 1976b: Late Middle Cambrian agnostid trilobites from the Gunns Plains area, northwestern Tasmania. Pap. Proc. R. Soc. Tasm. 110: 1-18.
JAGO, J. B. \& DAlly, B., 1974: The trilobite Clavagnostus Howell from the Cambrian of Tasmania. Palaeontology 17: 95109 .

JAGO, J.B. \& WEBERS, G.F., 1992: Middle Cambrian trilobites from the Ellsworth Mountains, West Antarctica. Geol. Soc. Amer. Mem. 170: 101-124.

Kobayashi, T., 1935: The Cambro-Ordovician formations and faunas of South Chosen. Palaeontology, part 3. Cambrian faunas of South Chosen with special study on the Cambrian trilobite genera and families. J. Fac. Sci., Tokyo Univ. sect. 2(4): 49-344.

Kobayashi, T., 1939: On the agnostids (Part 1). J. Fac. Sci., Tokyo Univ. sect. 2, 5(5): 69-198.

LAURIE, J.R., 1988: Revision of some Australian Ptychagnostinae (Agnostida, Cambrian). Alcheringa 12: 169-205.

LAURIE, J.R., 1989: Revision of species of Goniagnostus Howell and Lejopyge Corda from Australia (Agnostida, Cambrian). Alcheringa 13: 175-191.

Laurie, J.R., JAGO, J.B. \& BAO JinSONG, 1995: Revicw of Tasmanian Cambrian biostratigraphy. Aust. Geol. Surv. Organ. Rec. 1995/69: 1-32.

Lermontova, E.V., 1940: [Arthropoda]. In Vologdin, A. (Ed.): [Atlas of the leading forms of the fossil faunas of the USSR] 1: 112-157. Moscow-Leningrad: Gos. Izdat. Geol. Lit. (in Russian).

Linnarsson, J.G.O., 1869: Om Vestergötlands Cambriska och Siluriska aflagringar. K. Svenska Vetensk.-Akad. Handl. 8(2): $1-89$

Lisogor, K.A., Rozov, S.N, \& Rozova, A.V., 1988: Correlation of Middle Cambrian deposits of the Lesser Karatau and Siberian platform according to trilobites. In Zhuravleva, I.T. \& Repina, L.N. (Eds): Cambrian of Siberia and Middle Asia. Trans. Acad. Sci. USSR, Siberian Branch, Inst. Geol. Geophys. 720: 54-82 (in Russian).

Lorenz, T., 1906: Beiträge zur Geologie und Palacontologie von Ostasien unter besonderer Berüchsichting der Provinz Schantung in China, 2 Palacontologischer Teil. Dtsch. Geol. Ges. 58: 53-108.

Lu Yanhao, 1964: Cambrian trilobites. In Wang Yu (Ed.): HANDBOOK OF INDEX FOSSILS OF CHINA, HUNAN REGION. Geology Press, Beijing: 26-39 (in Chinese).

LU YanHaO \& LIN HuAnLING, 1989: The Cambrian trilobites of western Zhejiang. Palaeont. Sin. 178, n.s. B, 25: 1-285 (in Chinese with English summary).

Lu Yanhao, Zhang Wentang, Zhu Zhaoling, Qian Yiyuan \& XIANG LIwEN, 1965: [Chinese fossils of all groups; Trilobites of China]. Vol. 1, 1-362; vol. 2, 363-766. Science Press, Beijing (in Chinese).

Lu Yanhao, Zhu ZhaOling, Qian YiYuan, Lin Huanling, Zhou ZIYI \& YUAN KEXIN, 1974: Bioenvironmental control hypothesis and its application to Cambrian biostratigraphy and palacozoogeography. Mem. Nanking Inst. Geol. Palaeont. 5: 27-126 (in Chinese).

M'Cor, F., 1849: On the classification of some British fossil Crustacea, with notices of new forms in the university collection at Cambridge. Ann. Mag. Nat. Hist. (London), ser. 2(4): 161-179, 392-414.

MeEK, F.G., 1873: Preliminary paleontological report, consisting of lists of fossils, with remarks on the age of the rocks in which they were found. U.S. Geol. Surv. Territory, 6th Ann. Rep.: 429-518.

ÖrIK, A.A., 1961: The geology and palaeontology of the headwaters of the Burke River, Queensland. Bull. Bur. Miner. Resour. Geol. Geophys. Aust. 53: 1-249.

ÖPIK, A.A., 1967: The Mindyallan fauna of north-western Queensland. Bull. Bur. Miner. Resour. Geol. Geophys. Aust. 74: vol. 1, 404 pp.; vol. 2, 167 pp., 67 pl.

ÖpIK, A.A., 1979: Middle Cambrian agnostoids; systematics and biostratigraphy. Bull. Bur. Miner. Resour. Geol. Geophys. Aust. 172: vol. 1, 188 pp.; vol. 2, pl. 1-67. 
Paimer, A.R., 1968: Cambrian trilobites of east-central Alaska. U. S. Geol. Surv. Prof. Pap. 559B: 1-115.

Peng Shanchi \& Robison, R.A., 2000: Agnostoid biostratigraphy across the Middle-Upper Cambrian boundary in Hunan, China. Paleont. Soc. Mem. 53: 1-104.

RasetTI, F., 1967: Lower and Middle Cambrian trilobite faunas from the Taconic sequence of New York. Smith. Misc. Coll. 152 (4): 1-111.

Robison, R.A., 1964: Late Middle Cambrian faunas from western Utah. J. Paleontol. 38: 510-566.

Robison, R.A., 1982: Some Middle Cambrian agnostoid trilobites from western North America. J. Paleontol. 56: 132-160.

Robison, R.A., 1984: Cambrian Agnostida of North America and Greenland, Part 1, Ptychagnostidae. Univ. Kansas Paleont. Contr. Pap. 109: 1-59.

Robison, R.A., 1988: Trilobites of the Holm Dal Formation (late Middle Cambrian), central North Greenland. Meddr Gronland Geosci. 20: 23-103.

Robison, R.A., 1994: Agnostoid trilobites from the Henson Gletscher and Kap Stanton formations (Middle Cambrian), North Greenland. Bull. Gronlands Geol. Unders. 169: 25-77.

Romanenko, E.V., 1985. Trilobites from the Middle-Upper Cambrian boundary beds of Altay. Paleontol. J. 1985(4):54-63 (in Russian; also English edition 1985(4): 64-74).

Rushton, A.W.A., 1978: Fossils from the Middle-Upper Cambrian transition in the Nuneaton district. Palaeontology 21: 245-283.

SALTER, J.W., 1864: A monograph of the British trilobites from the Cambrian, Silurian and Devonian formations. Monogr. Palaeontogr. Soc, London: $80 \mathrm{pp}$.

Shergold, J.H. \& Laurie, J.R., 1997: Suborder Agnostina. In Kaesler, R.L. (Ed.): TREATISE ON INVERTEBRATE PALEONTOLOGY, PART O, ARTHROPODA 1 (revised). Geological Society of America and University of Kansas Press, Lawrence: 331-383.
Shergold, J.H., Laurie, J.R. \& Sun XiaOwen, 1990: Classification and review of the trilobite order Agnostida Salter, 1864: an Australian perspective. Rep. Bur. Miner. Resour. Geol. Geophys. Aust. 296: 1-93.

WALCOTT, C.D., 1911: Cambrian geology and paleontology 2, No. 4. Cambrian faunas of China. Smith. Misc. Coll. 57: 69-108.

WALCOTT, C.D., 1916: Cambrian geology and palaeontology of Cambrian trilobites. Smith. Misc. Coll. 64: 303-456.

WestergAro, A.H., 1946: Agnostidea of the Middle Cambrian of Sweden. Sver. Geol. Unders. Avh. Ser. C, no. 477: $1-141$.

Westrop, S. R., LudVIGSEN, R. \& Kindle, C.H., 1996: Marjuman (Cambrian) agnostoid trilobites of the Cow Head Group, Western Newfoundland. J. Paleont. 70: 804-829.

Whitehouse, F.W., 1936: The Cambrian faunas of north-eastern Australia, parts 1 and 2. Mem. Qld. Mus. 11: 59-112.

WhiteHOUSE, F.W., 1939: The Cambrian faunas of north-eastern Australia, Part 3. Mem. Qld. Mus. 11: 179-282.

XiANG LIWEN \& ZHANG TaIRONG 1985: Systematic description of trilobites. In Wang Ziguo (Ed.): Stratigraphy and trilobite faunas of the Cambrian in the western part of the northern Tianshan, Xinjiang. Minist. Geol. Miner. Resour., Geol. Mem. Ser. 2(4), 64-136 (in Chinese, English summary).

ZHANG WENTANG (Chang, W.T.), 1963: A classification of the Lower and Middle Cambrian trilobites from north and northeastern China, with description of new families and genera. Acta Palaeont. Sin. 11:447-487 (in Chinese with English summary).

ZhaNG WeNTANG \& JeLL, P.A., 1987: CAMBRIAN TRILOBITES OF NORTH CHINA; CHINESE CAMBRIAN TRILOBITES HOUSED IN THE SMITHSONIAN INSTITUTE. Science Press, Beijing: $459 \mathrm{pp}$.

(accepted 25 June 2001) 